\title{
Respiratory and Glycolytic Response of Suspension-cultured 'Passe Crassane' Pear Fruit Cells to Elevated $\mathrm{CO}_{2}$ Concentrations
}

\author{
Eduardo L. Kerbel', Adel A. Kader, and Roger J. Romani ${ }^{2}$ \\ Department of Pomology, University of California, Davis, CA 95616 \\ Additional index words. glycolysis, phosphofructokinase, fructose 6-phosphate, fructose 1,6-bisphosphate
}

\begin{abstract}
Suspension-cultured 'Passe Crassane' pear fruit (Pyrus communis L.) cells in aging media were ventilated with air or air $+20 \% \mathrm{CO}_{2}$ for 4 days at $26 \mathrm{C}$. Cells exposed to elevated $\mathrm{CO}_{2}$ exhibited reduced respiration $\left(\mathrm{O}_{2}\right.$ consumption). Ethylene production of both air and $\mathrm{CO}_{2}$-treated cells also declined to barely discernible levels by day 3. Fructose 6-phosphate (F6P) accumulated, while levels of fructose 1,6-bisphosphate (F1, 6-P $)$, and activities of ATP and PPi phosphofructokinases (PFK and PFP) declined in response to elevated $\mathrm{CO}_{2}$. These results indicate an inhibitory effect of $\mathrm{CO}_{2}$ at the site of action of both phosphofructokinases in the glycolytic pathway, which could account, at least in part, for the observed reduction in respiration. The responses to elevated $\mathrm{CO}_{2}$ levels of the cell suspension system and intact pear fruit ventilated with air $+10 \% \mathrm{CO}_{2}$ are compared, revealing a close similarity.
\end{abstract}

Although elevated $\mathrm{CO}_{2}$ is often used to retard the senescence of fruits and vegetables, little is known about its mode of action on respiratory metabolism (Kader, 1986). We have recently reported (Kerbel et al., 1988), however, that exposure of pear fruit to $10 \% \mathrm{CO}_{2}$ for 4 days at $20 \mathrm{C}$ resulted in a significant reduction in the activities of ATP:phosphofructokinase (PFK) and PPi:phosphofructokinase (PFP), and in levels of fructose 1,6-bisphosphate $\left(\mathrm{F} 1,6-\mathrm{P}_{2}\right)$ along with a discernible rise in the levels of fructose 6-phosphate (F6P) and fructose 2,6-bisphosphate $\left(\mathrm{F} 2,6-\mathrm{P}_{2}\right)$. There was little change in the activity or levels of other glycolytic enzymes or intermediates.

As a means of facilitating further study of the effects of elevated $\mathrm{CO}_{2}$ on glycolytic metabolism in pear fruit tissue, we examined the response of suspension-cultured pear fruit cells. Plant cell cultures have been used extensively in the study of carbohydrate metabolism with good evidence for the presence and operation of the glycolytic pathway (Fowler, 1978; Stafford and Fowler, 1983). Moreover, there is appreciable evidence (Romani, 1987) that senescent, cultured pear cells are useful in studying some specific aspects of whole-fruit physiology, including the respiratory response to limiting $\mathrm{O}_{2}$ tension (Brady and Romani, 1988; Boersig et al., 1988). Of interest in this study was the metabolic response of the cultured cells to elevated $\mathrm{CO}_{2}$ and whether the response mirrored that observed in pear fruit.

\section{Materials and Methods}

Cell cultures. An established strain of 'Passe Crassane' pear fruit cells was grown in a complete medium of mineral salts and organic nutrients, as described in detail by Pech and Romani (1979), but containing $0.5 \mathrm{mg}$ rather than $1 \mathrm{mg} 2,4$ dichlorophenoxyacetic acid (2,4-D) per liter. Cell suspensions were grown at $26 \pm 1 \mathrm{C}$ for 7 days and then for 7 days in medium lacking the hormone. During the latter incubation period, flasks containing the cells were flushed continuously with air at $\approx 60$

\footnotetext{
Received for publication 12 Sept. 1988. We are grateful to Betty Hess, Dept of Pomology, UC Davis, for expert technical assistance. The cost of publishing this paper was defrayed in part by the payment of page charges. Under postal regulations, this paper therefore must be hereby marked advertisement solely to indicate this fact.

'Assistant Professor, Dept. of Horticulture, 106D Horticulture Field Laboratory, 1707 S. Orchard St., Univ. of Illinois, Urbana, IL 61801.

${ }^{2}$ To whom reprint requests should be addressed.
}

$\mathrm{ml} \cdot \mathrm{min}^{-1}$. To achieve a senescent state the cells were then transferred to "aging" medium that consisted of one-fourth the concentration of nutrients found in the complete growth medium, no 2,4-D, but supplemented with $0.4 \mathrm{M}$ mannitol and $0.015 \mathrm{M}$ sucrose. Cell cultures were maintained on a rotary shaker at $\approx 110 \mathrm{rpm}$.

Exposure to elevated $\mathrm{CO}_{2}$ The cell suspension in aging medium was distributed into $250-\mathrm{ml}$ Erlenmeyer flasks $(125 \mathrm{ml}$ of suspension per flask). Sterile millipore filters were attached to flask inlets and outlets to maintain sterility and each flask was supplied with continuous air flow at $55 \mathrm{ml} \cdot \mathrm{min}^{-1}$. Following ventilation with air for 1 day, half the flasks were switched to air $+20 \% \pm 0.5 \% \mathrm{CO}_{2}$. The $\mathrm{CO}_{2}$ level was attained by premixing measured streams of air and $100 \% \mathrm{CO}_{2}$ and tested daily using a Carle model 111 thermal conductivity GC. All flasks were shaken continuously at $\approx 190 \mathrm{rpm}$. The experiments were run for 4 days at $26 \pm 1 \mathrm{C}$.

Oxygen uptake (respiration) was monitored daily on each of three flasks per treatment using an on-stream Applied Electrochemistry Oxygen Analyzer (Model S-3A) to measure $\mathrm{O}_{2}$ in the incoming and effluent air. Samples of the effluent gas from the culture flasks were taken with a needle and syringe and injected into a Carle Model 211 FID gas chromatography equipped with an activated alumina column to measure $\mathrm{C}_{2} \mathrm{H}_{4}$.

Estimation of culture volume, cell weight, and percentage of living cells. Culture volume was estimated by placing $12 \mathrm{ml}$ of cell suspension in a graduated, conical centrifuge tube and noting packed cell volume (PCV) following centrifugation at 600 $\times g$ for $5 \mathrm{~min}$. Cell fresh weight was assessed after collecting the cells on the cheesecloth pad with gentle vacuum. The percentage of dead cells was estimated by actual count after selective staining with Evans blue $(0.5 \%$, w/v) (Puschmann and Romani, 1983).

Preparation of extracts. Cell samples were extracted daily for analysis of glycolytic intermediates and enzymes. Cells contained in three individual $125-\mathrm{ml}$ samples (flasks) per treatment were collected under mild vacuum on two layers of cheesecloth placed on a Buchner funnel. The filtrate was set aside for subsequent $\mathrm{pH}$ measurement. The mass of cells was quickly transferred into liquid $\mathrm{N}_{2}$ and ground to a fine powder in a precooled mortar and pestle. The powder was extracted immediately for glycolytic intermediates and enzymes (Kerbel et al., 1988). The preparation of extracts was conducted at or below 4C. Each final supernatant from the extractions was transferred to a 1.5- 
$\mathrm{ml}$ microcentrifuge vial that was dropped into liquid $\mathrm{N}_{2}$ for 5 to 10 rein, stored at $-75 \mathrm{C}$ for 1 to 2 weeks, and then analyzed. Recovery experiments were done to estimate losses of metabolites and enzyme activities during extraction. Resultant recoveries ranged from $89 \%$ to $97 \%$.

Assay of intermediates and enzymes. G1ycolytic intermediates and aldolase, phosphoglucose isomerase (PGI), PFK, and PFP were assayed spectrophotometrically as described by Kerbel et al. (1988). All biochemical, including substrates and coupled assay enzymes, were obtained from Sigma (St. Louis, Me.). Extractable protein was estimated according to Bradford (1976) using BSA as the standard.

Two entirely separate experiments were conducted with triplicate samples for each variable and triplicates of each assay.

\section{Results}

Constancy of cell number and cell vitality. Essentially, no changes in PCV values were observed over the 4 days of the experiments, which confirmed that cells remained quiescent after transfer to aging media. Throughout these experiments, the percentage of living cells ranged between $88 \%$ and $92 \%$ and no significant differences were noted between air- and $\mathrm{CO}_{2}$-treated cells (data not shown).

Effects of $\mathrm{CO}_{2}$ on respiration rates and ethylene production. Exposure of the cultured cells to air $+20 \% \mathrm{CO}_{2}$ substantially reduced $\mathrm{O}_{2}$ consumption (Fig. 1A). Ethylene production by $\mathrm{CO}_{2}-$ treated cells decreased somewhat more rapidly than that of the controls, but the difference was relatively small (Fig. 1B).

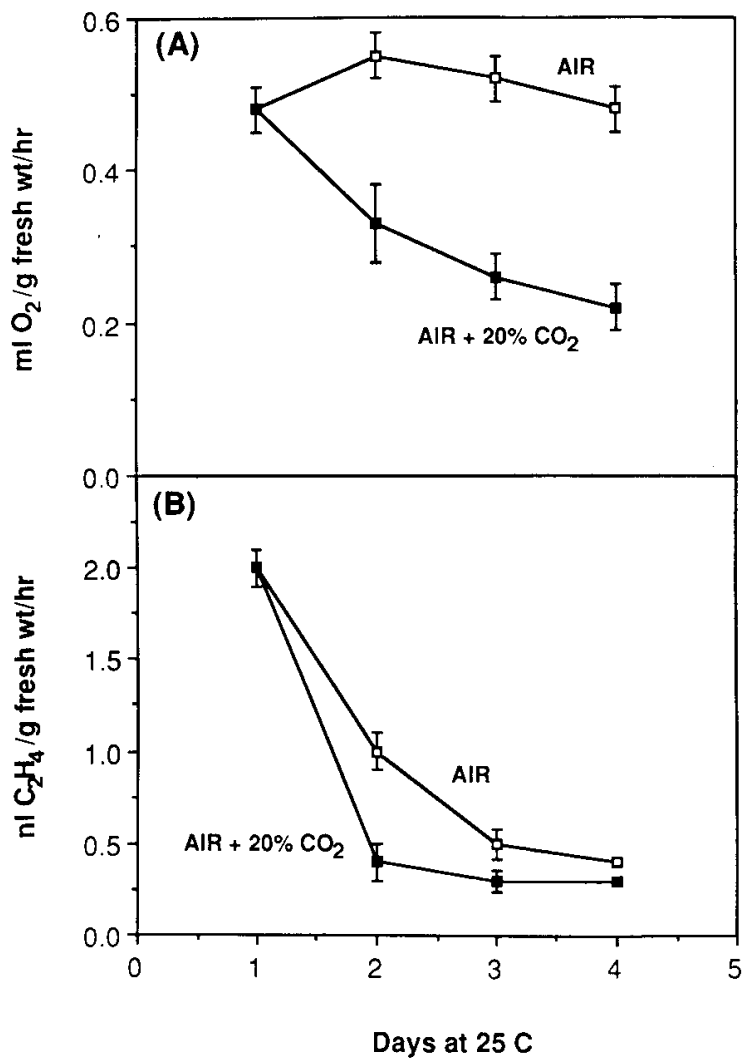

Fig. 1. Respiration rates $\left(\mathrm{O}_{2}\right.$ consumption) (A) and ethylene production (B) of 'Passe Crassane' pear fruit cells in aging medium during exposure to air or air $+20 \% \mathrm{CO}_{2}$ for 4 days at $26 \mathrm{C}$. All samples were exposed to air for the first 24 hr. Bars represent $S D, n=6$ at day $1, \mathrm{n}=3$ thereafter.

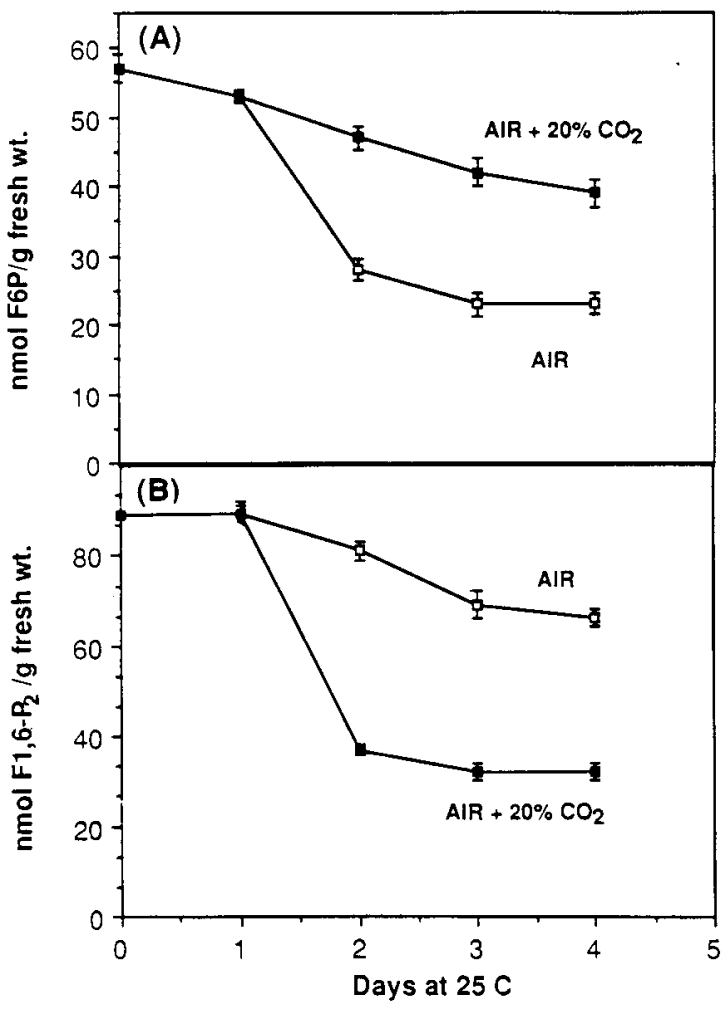

Fig. 2. Changes in fructose 6-phosphate (A) and fructose 1,6-bisphosphate (B) levels in 'Passe Crassane' pear fruit cells in aging medium during exposure to air or air $+20 \% \mathrm{CO}_{2}$ for 4 days at $26 \mathrm{C}$. Bars represent $S D, n=6$ at day $1, n=3$ thereafter.

Effects of $\mathrm{CO}_{2}$ on glycolytic intermediates and enzymes. The glycolytic intermediates and enzymes that showed significant changes in response to high $\mathrm{CO}_{2}$ were those that had demonstrated a notable change upon exposure of intact pear fruit to elevated $\mathrm{CO}_{2}$ (Kerbel et al., 1988). Elevated $\mathrm{CO}_{2}$ arrested the loss of F6P (Fig. 2A), and substantially reduced the levels of F1,6- $\mathrm{P}_{2}$ (Fig. 2B).

No significant differences were observed in the activities of aldolase or PGI between cells exposed to air or air $+20 \% \mathrm{CO}_{2}$ (data not shown). However, a substantial reduction in the activities of PFK (Fig. 3A) and PFP (Fig. 3B) in aging cells was noted in extracts from $\mathrm{CO}_{2}$-treated cells.

A comparison of the response to elevated $\mathrm{CO}_{2}$ by the in vitro cellular system and that by intact pear fruit reported in a comparable study (Kerbel et al., 1988) is presented in Fig. 4.

\section{Discussion}

Measurements of PCV over time confirmed that cells that had been grown in media containing $0.5 \mathrm{mg} 2,4-\mathrm{D} /$ liter no longer underwent cell division when transferred to aging medium. The stability in cell number and vitality indicates that the observed $>50 \%$ reduction in the rate of respiration under elevated $\mathrm{CO}_{2}$ is an intrinsic metabolic response and not a reduction in the number of living cells. The rapid decline in ethylene production by aging cells makes it difficult to confirm what appears to be an accentuation of the decline by exposure to $20 \% \mathrm{CO}_{2}$. In further studies, pear cells whose ethylene production has been enhanced by 1-aminocyclopropane-1-carboxylic acid (Puschmann and Romani, 1983), could be used to amplify the $\mathrm{CO}_{2}$ effect. 


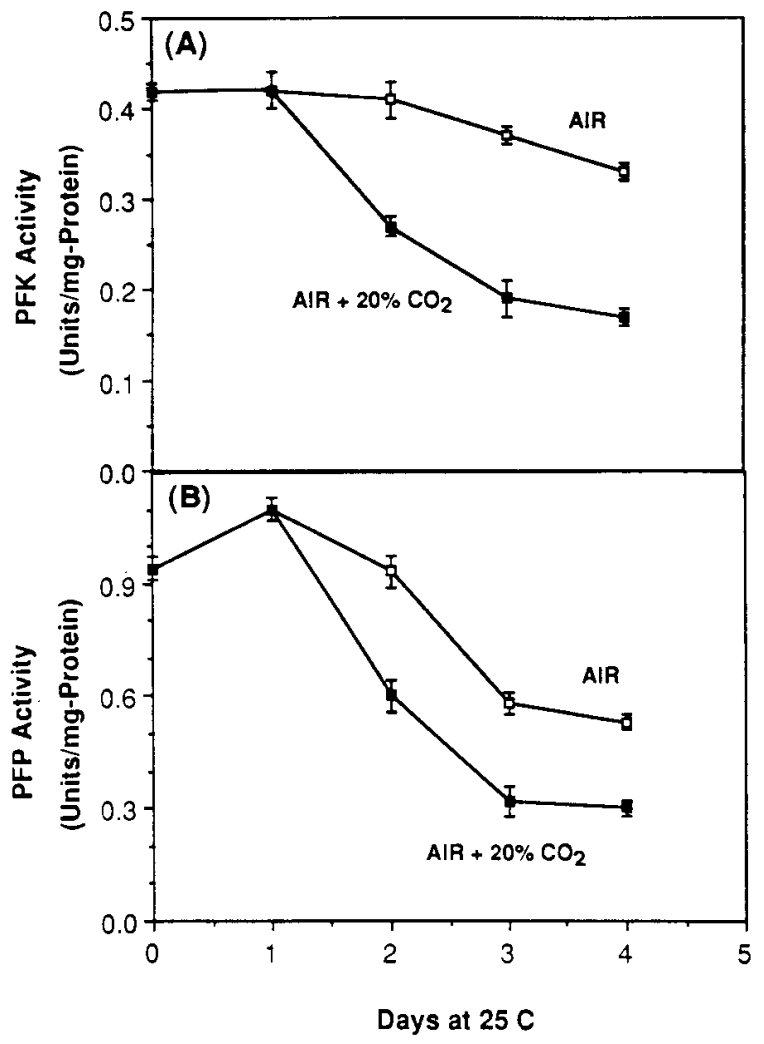

Fig. 3. Activities of (A) ATP:phosphofructokinase (PFK) and (B) PPi:phosphofructokinase (PFP) in 'Passe Crassane' pear fruit cells in aging medium, during exposure to air or air $+20 \% \mathrm{CO}_{2}$ for 4 days at $26 \mathrm{C}$. Bars represent $S D, n=6$ at day $1, n=3$ thereafter.

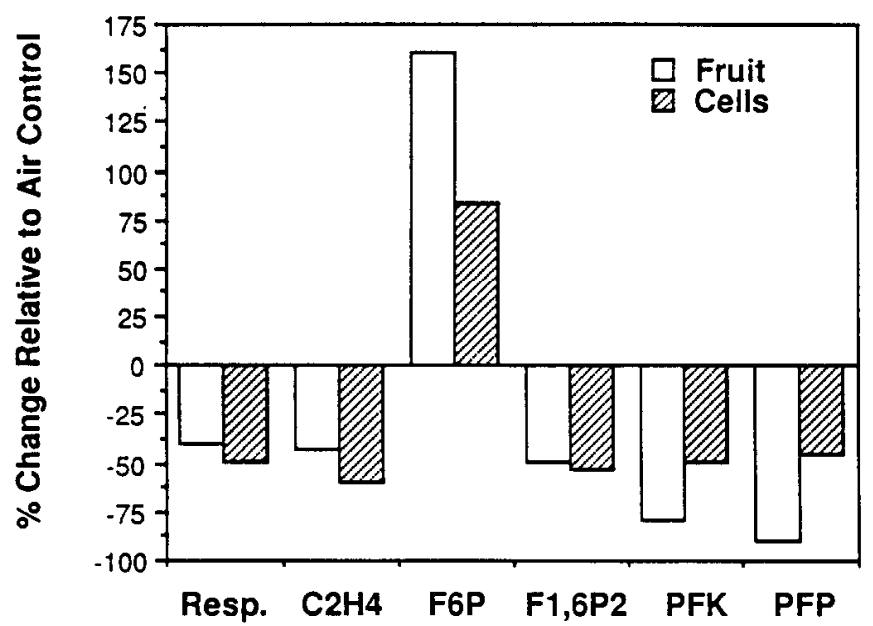

Fig. 4. Comparison of elevated $\mathrm{CO}_{2}$ effects on the respiration rates $\left(\mathrm{O}_{2}\right.$ consumption $), \mathrm{C}_{2} \mathrm{H}_{4}$ production, $\mathrm{F} 6 \mathrm{P}$, and $\mathrm{F} 1,6-\mathrm{P}_{2}$ levels; and PFK and PFP activities of intact 'Bartlett' pear fruit and suspensioncultured 'Passe Crassane' pear fruit cells in aging medium. Columns represent values after exposing intact fruit to air $+10 \% \mathrm{CO}_{2}$ at $20 \mathrm{C}$ for 3 days, and cell suspensions to air $+20 \% \mathrm{CO}_{2} 26 \mathrm{C}$ for 3 days. The data on pear fruit are derived from Kerbel et al. (1988).

A rapid and substantial increase in the levels of F1,6- $\mathrm{P}_{2}$ and decrease in F6P, shown to accompany the respiratory climacteric (Solomos and Laties, 1974) or when plant tissue is transferred to anoxic conditions (Kobr and Beevers, 1971), have been attributed to an activation of PFK. By analogy, and based also on what we have observed with whole fruit (Kerbel et al., 1988), we propose that the accumulation of F6P (Fig. 2A) and the reduction of $\mathrm{F} 1,6-\mathrm{P}_{2}$ (Fig. 2B) indicate an inhibitory effect of elevated $\mathrm{CO}_{2}$ on PFK. Moreover, the reduction in PFK (Fig. 3A) and PFP (Fig. 3B) activities is consistent with this proposed effect of $\mathrm{CO}_{2}$.

It is sometimes difficult, particularly with respect to tissues or cells undergoing physiological change, to differentiate between changes in enzyme activity and extractability. The fact that the same extract was assayed for the various enzymes and that there were no differences in the activities of aldolase or PGI between air and $\mathrm{CO}_{2}$-treated cells, whereas PFK and PFP activities decreased more than $40 \%$ under high $\mathrm{CO}_{2}$, suggests that the reduction in the activity of the latter enzymes was not artifactual.

A reduction of PFK and PFP activities by elevated $\mathrm{CO}_{2}$ could result from an inhibition of PFK and PFP synthesis or by inactivation of preexisting PFK and PFP. No differences in total protein content among air and $\mathrm{CO}_{2}$-treated cells were discerned (data not shown), but that does not rule out changes in the levels of specific proteins.

Regulation of glycolysis by PFK depends to a great extent on $\mathrm{pH}$ (Turner and Turner, 1980). Theoretical calculations and experimental data indicate that $\mathrm{CO}_{2}$ concentrations $>5 \%$ will generally lower intracellular $\mathrm{pH}$ (Bown, 1985; Siriphanich and Kader, 1986). We did not observe changes in media $\mathrm{pH}$ as a result of exposure to $\mathrm{CO}_{2}$, but that may bear little reflection on cytoplasmic $\mathrm{pH}$. As pointed out by Mitz (1979), $\mathrm{CO}_{2}$ can have direct effects on metabolic activities distinct from those mediated by changes in $\mathrm{pH}$. He proposed that transient localized concentration changes of $\mathrm{CO}_{2}$ within parts of the cell can markedly influence cell metabolism through dynamic changes in constituents. High $\mathrm{CO}_{2}$ concentrations may allow certain intermediates and cofactors to accumulate to a point where secondary reactions can take place. Plant PFK can be inhibited, for example, by ATP, ADP, phosphoenol pyruvate, 2- or 3-phosphoglyceric acid, citrate, and malate (Rhodes, 1983; Turner and Turner, 1980). Carbon dioxide-responsive cell cultures would clearly facilitate future searches for the mediators of the $\mathrm{CO}_{2}$ effect on glycolysis.

A comparison of the effects of high $\mathrm{CO}_{2}$ on several responses of intact fruit and cell suspension is shown in Fig. 4. Some differences in magnitude aside, the trend and direction of these responses by intact fruit and cell suspensions were essentially the same. This similarity suggests that, although large differences undoubtedly exist between cells in situ and in vitro, the latter are useful for the study of specific aspects of fruit ripening and metabolism. However, extrapolations from data obtained with cells or with experimental conditions, i.e., $20 \% \mathrm{CO}_{2}$ at $26 \mathrm{C}$ chosen to amplify cellular response, to practical postharvest technologies (e.g., preconditioning in air $+10 \%$ to $20 \% \mathrm{CO}_{2}$ at 0 to $10 \mathrm{C}$ for 10 to 14 days) is problematic and must be done with caution and with further appropriate experimentation addressing concerns for injury and other physiological effects.

Not shown in the foregoing were the divergent response of cells grown in twice the level of $2,4-\mathrm{D}$; i.e., $1 \mathrm{mg} \cdot \mathrm{ml}^{-1}$ When used as a test system, after being sub-cultured in 2,4-D-free medium for 1 week and transferred to aging medium, these cells exhibited respiratory and $\mathrm{C}_{2} \mathrm{H}_{4}$ responses to $20 \% \mathrm{CO}_{2}$ very much like those shown in Fig.1. However, accompanying changes in F6P, F1,6 $\mathrm{P}_{2}, \mathrm{PFK}$, and PFP, though similar in magnitude, were in the opposite direction (Kerbel, 1987) of those shown in 
Figs. 2 and 3. Another distinguishing characteristic of cell cultures held with the higher initial levels of 2,4-D was their growth; i.e., a measurable increase in PCV during the first 2 to 4 days after transfer to aging medium. Thus, it is likely that a significant portion of the cells was more juvenile than senescent during this period. With due regard for precaution in extrapolating from cultured cells to intact tissue, these observations nonetheless imply that 1) the cultured cells are amenable to physiological manipulation via phytohormone level much as originally proposed by Pech et al. (1975), and 2) gross metabolic responses of fruit cells - and possibly of fruit - to stressful atmospheric conditions may be the result of intracellular adjustments that vary appreciably with physiological state.

\section{Literature Cited}

Boersig, M.R., A.A. Kader, and R.J. Romani. 1988. Aerobic-anaerobic respiratory transition in pear fruit and cultured pear fruit cells. J. Amer. Soc. Hort. Sci. 113(6):869-873.

Bown, A.W. 1985. $\mathrm{CO}_{2}$ and intracellular pH. Plant Cell \& Environ. $8: 459-465$.

Bradford, M.M. 1976. A rapid and sensitive method for the quantitation of microgram quantities of protein utilizing the principle of protein-dye binding. Anal. Biochem. 72:248-254.

Brady, C.J. and R.J. Romani. 1988. Respiration and protein synthesis in non-growing cultured pear fruit cells in response to ethylene and modified atmospheres. Plant Physiol. 87:571-576.

Fowler, M.W. 1978. Regulation of carbohydrate metabolism in cell suspension cultures, p. 443-452. In: T.A. Thorpe (ed.). Frontiers in plant tissue culture. Univ. of Calgary, Calgary, Albt., Canada.

Kader, A.A. 1986. Biochemical and physiological basis for effects of controlled and modified atmospheres on fruits and vegetables. Food Technol. 40(5):99-100, 102-104.

Kerbel, E.L. 1987. Effects of elevated $\mathrm{CO}_{2}$ concentrations on glycolysis in intact 'Bartlett' pear (Pyrus communis L.) fruit and suspension-cultured 'Passe Crassane' pear fruit cells. PhD Diss., Univ. Calif., Davis.
Kerbel, E.L., A.A. Kader, and R.J. Romani. 1988. Effects of elevated $\mathrm{CO}_{2}$ concentrations on glycolysis in intact 'Bartlett' pear fruit. Plant Physiol. 86:1205-1209.

Kobr, M.J. and H. Beevers. 1971. Gluconeogenesis in the castor bean endosperm. Plant Physiol. 47:48-52.

Mitz, M.A. 1979. $\mathrm{CO}_{2}$ Biodynamics: A new concept of cellular control. J. Theor. Biol. 80:537-551.

Pech, J.-C., C. Ambid, A, Latche, A. Diaria, and J. Fallot. 1975. Culture de tissus et de suspensions cellulaires de fruits. Moyen d'étude de certains aspects de la maturation. Facteurs et regulation de la maturation des fruits. CNRS, Paris. p. 21 1-220.

Pech, J.C., R.J. Romani. 1979. Senescence of pear fruit cells cultured in a continuously renewed, auxin-deprived medium. Plant Physiol 63:814-817.

Puschmann, R. and R.J. Romani. 1983. Ethylene production by auxin deprived, suspension-cultured pear fruit cells in response to auxins, stress or precursor. Plant Physiol. 73:1013-1019.

Rhodes, M.J.C. 1983. Enzyme activities and postharvest changes, p. 99-121. In: M. Lieberman (ed.). Postharvest physiology and crop preservation. Plenum, New York.

Romani, R.J. 1987. Cell suspension cultures for the study of plant senescence, p. 390-404. In: J.M. Bonga and D.J. Durzan (eds.). Cell and tissue culture in forestry. vol. 2. Martinus Nijhoff, Dordrecht, Netherlands.

Siriphanich, J. and A.A. Kader. 1986. Changes in cytoplasmic and vacuolar $\mathrm{pH}$ in harvested lettuce as influenced by $\mathrm{CO}_{2}$. J. Amer. Soc. Hort. Sci. 111(1):73-77.

Solomos, T. and G.G. Laties. 1974. Similarities between the actions of ethylene and cyanide in initiating the climacteric and ripening in avocados. Plant Physiol. 54:506-511.

Stafford, A. and M.W. Fowler. 1983. Effect of carbon and nitrogen growth limitation upon nutrient uptake and metabolism in batch cultures of Catharanthus roseus L.G. Don. Plant Cell Tissue Organ Cult. 2:239-251.

Turner, J.F. and D.H. Turner. 1980. The regulation of glycolysis and pentose phosphate pathway, p. 279-316. In: D.D. Davies (ed.). The biochemistry of plants: A comprehensive treatise. vol. 2. Academic, New York. 